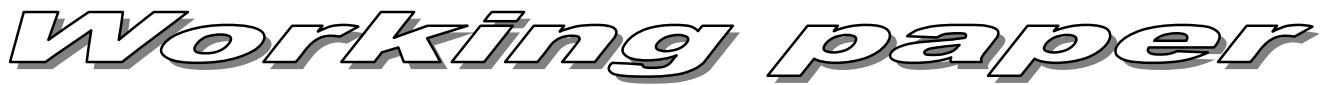 Wint
}

\author{
No. 68
}

Ondřej Schneider: Who Pays Taxes and Who Gets Benefits in the Czech Republic
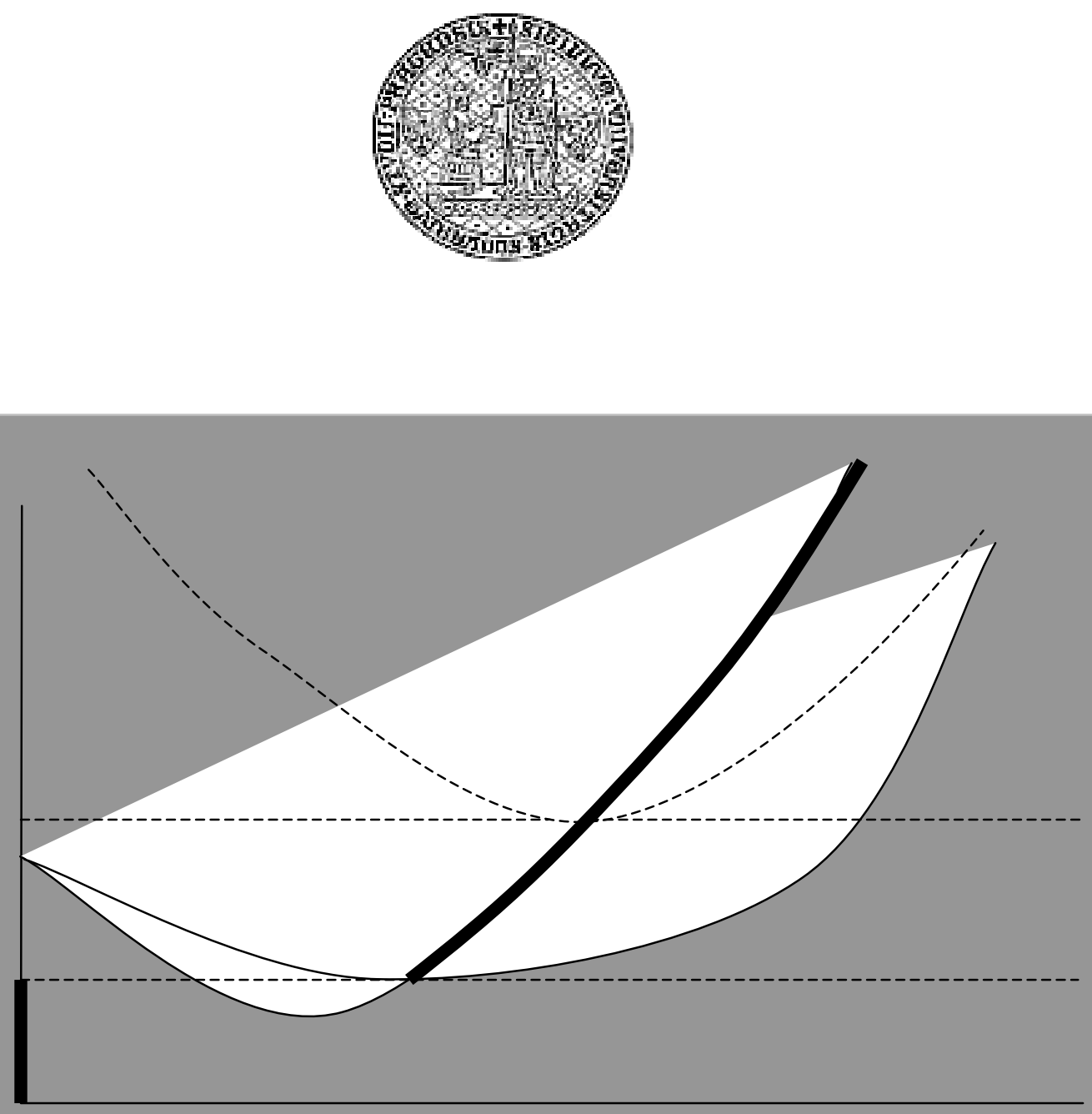

2004 


\title{
WHO PAYS TAXES AND WHO GETS BENEFITS IN THE CZECH REPUBLIC ${ }^{\mathrm{x}}$
}

\author{
Ondřej Schneider
}

\begin{abstract}
In this paper, we summarize our previous research into the distributive effects of the tax and social systems in the Czech Republic. We construct a measure of the total tax burden for ten income deciles and we measure it against social benefits distribution. Our analysis shows that the poorest decile gains significantly from the combined tax and social systems, as its income is lifted by almost a quarter, income of the five richest deciles is cut by approximately $40 \%$. This highly progressive nature of the Czech system is due to the fact that poorest households pay very low direct taxes (including social security contributions) and consume most of social benefits. This combination creates a substantial poverty trap for poorest households. Only regressive parts of the whole system are consumption taxes (excise taxes and to a larger extent value added tax). Our analysis, thus, confirms a high level of redistribution of income and strong disincentives for labor market participation of lowincome groups in the Czech Republic.
\end{abstract}

\section{Kdo jsou plátci daní a kdo jsou př́ijemci dávek v České republice}

Studie shrnuje výsledky analýz daňového a sociálního systému v České republice z hlediska jejich dopadu na různé př́ijmové skupiny obyvatelstva. V práci určujeme celkové daňové zatížení deseti př́ijmových decilů domácností a poměřujeme jej s úrovní sociálních dávek, které tyto skupiny dostávají. Ukazuje se, že čistými př́ijemci jsou jen domácnosti v prvním a druhém nejnižším decilu př́ijmového rozdělení. Padesát procent domácností s vyššími př́ijmy ovšem platí daně ve výši okolo $40 \%$. Tato progresivnost daňového a sociálního systému je způsobena zanedbatelnými přímými daněmi placenými nejchudšími domácnostmi, které přitom spotřebovávají nejvíce sociálních dávek. Zároveň ovšem vysoká progrese vede k vytváření pasti chudoby a odrazování od zapojení do oficiálního trhu práce.

JEL Classification: H2, I3

Keywords: tax policy, social policy, income distribution, tax burden.

Klíčová slova: daňová politika, sociální politika, daňové břemeno,rozdělení prř́jmů, přerozdělování

\footnotetext{
${ }^{\mathrm{x}}$ This research has been supported by a grant from the Czech Grant Agency No. 402/2004. The author would like to thank Tomáš Jelínek of the Institute for Social and Economic Analyses and Gabriela Hrubá of the IES FSV UK for an excellent research support and to Petra Štěpánková for discussions and useful comments. The responsibility for remaining all omissions and errors is, however, solely of the author.

*Institute of Economic Studies, Faculty of Social Sciences, Opletalova 26, Prague 1, 11000,. E-mail: schneider@fsv.cuni.cz.
} 


\section{Introduction}

In this paper we continue our research into the Czech social and tax systems and their impact on income distribution. In our previous research, we found that tax system in the Czech Republic is rather progressive; mainly die to progressivity of direct taxes while indirect taxes are mildly regressive. We also found that the social system benefits are targeted at poorer households, with some exception in the illness benefits and children allowances.

In this paper, we combine these two approaches and we construct a combined measure of the tax and social systems' impact on income distribution. Not surprisingly, we find that the combined effects of both systems share most features of the two subsystems, namely their progressivity in the lower part of the income distribution and higher neutrality in the upper part.

The paper is organized as follows: in the first section we briefly describe the Czech tax system, its main tax groups and we quantify their impact on the state budget. In the second section, the Czech social security systems, namely six major social benefits are described and their costs quantified. The third section then deals with a brief description of the data used in our analysis.

Fourth and fifth chapters bring analysis of distributive effects of the two systems: taxes and benefits. The sixth chapter then combines results from the two preceding chapters and estimates total effect on the household income distribution. The last chapter brings conclusions and some tentative policy-oriented analysis.

\section{Czech tax system}

The Czech tax system has been completely overhauled since 1989. In most respects, it now resembles a typical European tax system, characterized by high tax rates, especially on labor income, and efficient (measured by its tax revenue capacity) VAT system. In year 2001, the Czech government collected $38.6 \%$ of GDP in taxes (the rate went up to $39.2 \%$ of GDP in 2002 and probably even higher in 2004). By far, the biggest contributors were social security contributions that made up as much as $14.7 \%$ of GDP. Consumption taxes added $11.3 \%$ of GDP - VAT $6.9 \%$ and excise taxes levied on tobacco, alcohol and oil products $3.5 \%$ of GDP. Personal income taxes brought in 5\% of GDP, while corporate taxes further $4.2 \%$ of GDP see chart 1 below for details.

The one feature that makes the Czech system special is it's reliance on social security contributions. The Czech government collects by about 5\% of GDP more in social security contributions that an average EU15 country. Only France and Germany collect more from the social security contributions - see Table 1 . 
Chart 1: Czech tax revenues, 1993-2002 (\% of GDP)

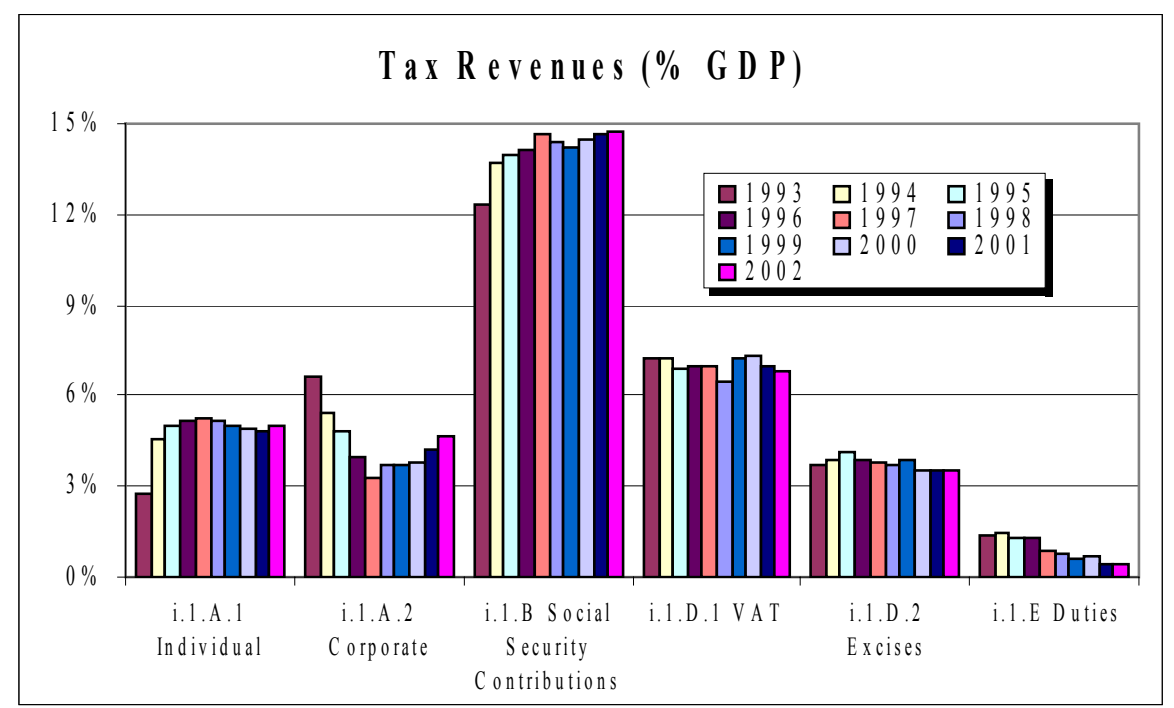

Source: Government Financial Statistics, author's calculations.

Table 1: Tax burden in the Czech Republic and in the EU, 2001

\begin{tabular}{lrrrr}
\hline & $\begin{array}{c}\text { Total tax } \\
\text { burden }\end{array}$ & Indirect taxes & Direct taxes & $\begin{array}{c}\text { Social security } \\
\text { contributions }\end{array}$ \\
\cline { 2 - 4 } in \% of GDP & \multicolumn{2}{c}{ in \% of total tax revenues } \\
\hline \hline Belgium & 46 & 29.6 & 39.2 & 31.2 \\
Denmark & 49.8 & 35.1 & 60.4 & 4.4 \\
Germany & 41.2 & 30.3 & 27.3 & 42.5 \\
Greece & 36.8 & 40.8 & 28.3 & 30.9 \\
Spain & 35.6 & 33.8 & 30.5 & 35.7 \\
France & 45.4 & 34.7 & 29.1 & 36.3 \\
Ireland & 31.2 & 43.6 & 41.9 & 14.5 \\
Italy & 42.6 & 35.3 & 35.7 & 29 \\
Luxemburg & 41.8 & 34.1 & 38.2 & 27.7 \\
Netherlands & 40 & 33.7 & 30.6 & 35.6 \\
Austria & 45.6 & 33.8 & 33.4 & 32.8 \\
Portugal & 35.9 & 41.4 & 27.8 & 30.9 \\
Finland & 46 & 29.9 & 43 & 27.1 \\
Sweden & 54.1 & 31.3 & 41.2 & 27.5 \\
United Kingdom & 37.5 & 37.8 & 45.2 & 17.1 \\
EU15 & 41.1 & 33.7 & 34.9 & 31.4 \\
United States & 29.6 & 16.7 & 48.4 & $24.2:$ \\
Japan & 27.1 & $16.5:$ & 35.5 & $36.9:$ \\
Czech Republic & 38.4 & 34.9 & 24.6 & 40.4 \\
\hline
\end{tabular}

Source: Eurostat, OECD, Czech finance ministry

Note: Data for USA and Japan are from 1997.

In the following sections we briefly review main tax subsystems. More detailed discussion can be found in Bronchi, Burns (2000) or in Hrubá (2004a, 2004b) 


\subsection{Personal income tax}

The Czech tax systems taxes personal incomes by a moderately progressive scale, where the marginal tax rate increases from $0 \%$ to $32 \%$. The highest bracket applies to incomes approximately $185 \%$ of the national average wage. Due to various tax credits, the average applied tax rate is $7.5 \%$ only. The state budget gains about $5 \%$ of GDP in the tax revenues. 1

\subsection{Social security contribution}

As we noted above, social security contributions represent the most important revenue source for the state budget: they bring about $15 \%$ of GDP every year. Formally, these contributions are supposed to cover budget expenditures on pensions, health care, illness benefits and unemployment benefits. In reality, however, until 1998 the contributions were higher than actual expenditures but the surplus was "absorbed" by the budget. Since then, however, the social benefits regularly exceed the contributions, the gap being covered by the general budget revenues.

The contributions are levied on all labor income at the rate of $47.5 \%$. This is one of the highest rates among the European countries, only France, Belgium, Hungary and Poland has higher rate in 2001, however the Czech Republic is the only one without an upper limit for social security contributions. Contributions are paid both by the employee and the employer, for the break-up see the Table 2.

Table 2: Social insurance contribution rates as of 2005

\begin{tabular}{llll}
\hline & Employee & Employer & Combined \\
\hline Pensions & $6.5 \%$ & $21.5 \%$ & 28 \\
Illness & $1.1 \%$ & $3.3 \%$ & $4.4 \%$ \\
Health care & $4.5 \%$ & $9.0 \%$ & $13.5 \%$ \\
Unemployment & $0.4 \%$ & $1.2 \%$ & $1.6 \%$ \\
TOTAL & 12.5 & 35.0 & 47.5 \\
\hline
\end{tabular}

Source: Czech Ministry for Labor and Social Affairs

Note: Until January 2004, pension insurance contributions were by 2 percentage points lower and unemployment insurance by 2 percentage points higher.

\section{2. $\quad$ Value added tax}

Value added tax is levied in the Czech Republic on all services and goods and is applied at two rates: 5\% and 19\%.2 The lower bracket consists of "socially sensitive" goods, as food, housing, drugs and some utilities. Indeed, the lower rate is applied so extensively, that the efficient VAT tax rate, calculated as the share of total VAT revenues in total consumption, is only 9\%.3 The VAT brought almost 7\% of GDP in 2001. The revenues increased further in 2004, as the government lowered the upper rate from 22 to $19 \%$, but moved many goods and services from the lower $5 \%$ bracket to the upper bracket.

\footnotetext{
${ }^{1}$ Further $3-5 \%$ of GDpare collected through corporate profit tax, but this tax is not analyzed in this paper, as there is no data on its distribution effects available.

${ }^{2}$ The paper deals with the 2001 data, though, when the upper VAT rate was $22 \%$.

${ }^{3}$ See Hrubá (2004a) for details.
} 


\subsection{Excise taxes}

Excise taxes are levied on fuel products, tobacco and alcohol. The tax is levied per valorem, i.e. the unit of taxation is a physical quantity of the good, not its price (or not exclusively). As the table 3 illustrates, the system of excise taxes is rather complex.

Table 3: Excise taxes in the Czech Republic, 2001

\begin{tabular}{lrrr}
\hline & \multicolumn{2}{c}{ Rate } & Rate \\
\hline \hline Liquors & CZK 234 per 1 of alcohol & Petroleum unleaded & CZK 10.84 per liter \\
Beer & CZK 24 per 100 l & Petroleum leaded & CZK 10.84 per liter \\
Cigarettes (short) & CZK 0.67 per piece & Diesel & CZK 8.15 per liter \\
Cigarettes (long) & CZK 0.79 per piece & Heating oil - light & CZK 8.15 per liter \\
Cigarette tobacco & CZK 855 per kilo & Heating oil - heavy & 0 \\
Chewing tobacco & CZK 44 per kilo & Liquid gas for transport & CZK 2.85 per kilo \\
Cigars & CZK 0.79 per piece & Liquid gas not for transport & 0 \\
\hline
\end{tabular}

Source: Ministry of finance

\section{Social Security System in the Czech Republic}

The Czech Republic posses a highly sophisticated and ubiquitous social security system. For purposes of this paper, we concentrate on following social benefits only: child allowance, social supplement, parental allowances, other social benefits, unemployment benefits and illness benefit as they are included in the household budget survey. ${ }^{4}$ Hereby analyzed benefits imply state expenditures of almost CZK $70 \mathrm{bn}$ in 2001 , i.e. $3.2 \%$ of GDP.

A detailed description of the social security system can be found in Schneider Jelínek (2001) or Schneider, Jelínek (2004), here we only briefly review individual benefits.

\subsection{Children allowances}

Children allowances represent supplementary income for the purpose of raising a child. Annual costs in 2001 were CZK 12.8bn. Families with income of up to triple of the minimum living standard for their type of family are eligible for some allowance. Entitlement lasts as long as the child is dependent. A dependent child is defined as any unmarried child under the age of 26 years as long as he/she is a student in a defined type of secondary or higher educational institution or cannot (due to a long-term illness or disability) earn any income. Until the age of 18 also a registered unemployed not receiving unemployment benefits is considered to be a dependent child.

\subsection{Social supplement when caring for a child}

It is additional supplementary income for families with a low income (defined as income below 160\% of MLS). Costs of the program were CZK 6bn in 2001.

\subsection{Parental allowance}

\footnotetext{
${ }^{4}$ In order to limit the scope of the analysis, we have left out most of the Social Insurance system, such as old-age and invalidity pensions, the whole range of benefits for disabled persons as these have to engage many specific features and aims.
} 
A payment to a parent caring personally full-time for a child 4 years old or younger or for a handicapped child under the age of 7 which is not placed in nursery, kindergarten or any other institution for preschool children. A parent is eligible for the benefits unless he/she receives health insurance, unemployment benefits or maternity leave benefits. Until 2004, the parent might earn the sum lower or equal to his/her personal minimum living standard at most in order to qualify for the benefit. The government budget paid out almos CZK 8bn in these benefits in 2001 .

\subsection{Unemployment Compensation System}

In January 1, 1996 the base for the maximum changed to the minimum living standard for an adult in a one-person household and currently the ceiling is 2.5 of the MLS (2.9 of MLS for unemployed in a retraining course). There is no minimum benefit since $1992 .{ }^{5}$ Benefits are not indexed to inflation, nor are they taxed.

\subsection{Illness benefits}

Illness benefits substitute lost income during short illness. They are financed from a special surcharge on the payroll tax - see above - and are redistributive in nature, as their level is topped. An ill worker is entitled to the benefits from the very first day of his/her illness and there is no cost-sharing by employers. It is no surprise, thus, that the system is often used for short-term off-loading of unneeded workers. On average, $7 \%$ of workers claim an illness on any working day in the Czech Republic. The costs of the illness benefit system, together with other social programs, are summarized below in the table 4 .

Table 4: Cost of selected social security programs in 2001 (CZK bn)

\begin{tabular}{ccccccc}
\hline & $\begin{array}{l}\text { Child } \\
\text { allowance }\end{array}$ & $\begin{array}{l}\text { Social } \\
\text { supplement }\end{array}$ & $\begin{array}{l}\text { Parental } \\
\text { allowance }\end{array}$ & $\begin{array}{l}\text { Other social } \\
\text { allowance }\end{array}$ & $\begin{array}{l}\text { Illness } \\
\text { benefits }\end{array}$ & $\begin{array}{l}\text { Unemployment } \\
\text { benefits }\end{array}$ \\
\hline \hline 2001 & 12,799 & 6,041 & 7,701 & 6,055 & 25,716 & 5,229 \\
\hline
\end{tabular}

Source: Ministry of finance

\section{Data description}

In order to get estimates of the distributive impact of both tax and social systems, we use the household survey, a regular and long-term panel study of more than 3,000 Czech households provided by the Czech Statistical Office (CSO). A detailed discussion of the data merits is to be found in Schneider, Jelínek (2001) or Schneider, Jelínek (2004).

The survey is representative with respect to the income, age, social status and number of children. Thus, it is very likely representative with respect to many social benefits, as they are mostly based on the income status of the family or on the number of children in the family. Also, taxes reflect the households' incomes rather closely, so the survey can be used for analyzing distributive effects of the tax system.

As we were mainly concerned with distribution impact of the tax and social security systems we used a constructed "market income" as a base for sorting households. The "market

\footnotetext{
${ }^{5}$ Unemployed are eligible to the minimum living standards, discussed above.
} 
income" is calculated from the household survey where the reported net income is adjusted for received social transfers and for paid taxes. The resulting "market income" should simulate income the household would have had if there had been no government taxes and transfers.

The survey covers households (as opposed to individuals) but it provides extensive demographic and income statistics, so it is rather straightforward to construct a distribution of incomes on individual basis, as we assumed that all family members have the same share in the family income. It is often argued that larger families enjoy "returns to scale" as some household expenses are similar for one-member family and for more numerous families. To that extent, the CSO provides "weights" of additional family members: while the first member counts for one unit, the remaining adults for 0.7 and children of age $0-13$ for 0.5 of the unit. We used this "adjusted consumption scale" in our calculations.

While this survey probably underweights both richest households (that have little incentive to cooperate with the CSO) and poorest households (that are difficult to reach and that may find the CSO questionnaires too complicated), it does provide the most comprehensive and complex set on information households' incomes and expenditures.

\section{Distributive effects of the tax system}

In this chapter we present a brief summary of the Czech tax system analysis published in more details in Hrubá (2004a and 2004b). First, it is worth noting that the average tax burden, paid by an average Czech household is significant: in 2001 Czech households paid on average $34.6 \%$ of their income in taxes. The largest item, by far, were social security contributions that absorbed almost a quarter of all household incomes.6 Value added taxes consumed $6 \%$ of income, income taxes a little more than $4 \%$ and excise taxes $2 \%$ of the average income - see table 5 .

Table 5: Average tax burden

\begin{tabular}{|c|c|c|c|c|c|c|c|}
\hline & $\begin{array}{l}\text { Market } \\
\text { income }\end{array}$ & $\begin{array}{c}\text { Social } \\
\text { security } \\
\text { contributions }\end{array}$ & $\begin{array}{c}\text { Income } \\
\text { tax }\end{array}$ & VAT & $\begin{array}{c}\text { Excise } \\
\text { taxes }\end{array}$ & $\begin{array}{l}\text { Other } \\
\text { taxes }\end{array}$ & Total \\
\hline Nominal (CZK) & 313134 & 87085 & 17666 & 17033 & 5632 & 227 & 127643 \\
\hline Tax burden & & $22.3 \%$ & $4.3 \%$ & $6.0 \%$ & $1.9 \%$ & $0.1 \%$ & $34.6 \%$ \\
\hline
\end{tabular}

However, as we were interested in the distributive effects of the tax system, we analyzed how the tax burden is spread across ten income groups. As the following table 6 illustrates, the Czech tax system is rather progressive, with a large rise in the tax level for the fourth and fifth income decile. In other words, while the poorest three deciles pay relatively low taxes, the fourth decile is somewhere in the middle and the richest $60 \%$ of households face high tax rates and there is little variation in their tax burden - see table 6 .

\footnotetext{
${ }^{6}$ We considered, however, the whole amount of social security contributions paid nominally by the employee and the employer, as being paid by the employee
} 
Table 6: Distribution of the tax burden

\begin{tabular}{crrrrrrrr}
\hline Decile & $\begin{array}{c}\text { Market } \\
\text { income }\end{array}$ & $\begin{array}{c}\text { Social security } \\
\text { contributions }\end{array}$ & $\begin{array}{c}\text { Income } \\
\text { tax }\end{array}$ & VAT & Excise taxes & Other taxes & $\begin{array}{c}\text { Tax } \\
\text { Total }\end{array}$ & $\begin{array}{c}\text { Eredits } \\
\text { credib }\end{array}$ \\
\hline \hline 1 & 74824 & $2.7 \%$ & $0.7 \%$ & $8.0 \%$ & $1.6 \%$ & $0.1 \%$ & $13.0 \%$ & $-8.3 \%$ \\
2 & 111860 & $6.8 \%$ & $1.2 \%$ & $6.7 \%$ & $1.9 \%$ & $0.1 \%$ & $16.9 \%$ & $-5.6 \%$ \\
3 & 157096 & $8.4 \%$ & $1.3 \%$ & $6.8 \%$ & $2.3 \%$ & $0.1 \%$ & $18.9 \%$ & $-4.8 \%$ \\
4 & 194196 & $20.8 \%$ & $3.4 \%$ & $6.8 \%$ & $2.4 \%$ & $0.1 \%$ & $33.5 \%$ & $-4.4 \%$ \\
5 & 246956 & $27.5 \%$ & $5.0 \%$ & $6.1 \%$ & $2.2 \%$ & $0.1 \%$ & $40.9 \%$ & $-3.8 \%$ \\
6 & 308002 & $30.3 \%$ & $5.3 \%$ & $5.9 \%$ & $2.0 \%$ & $0.1 \%$ & $43.5 \%$ & $-3.8 \%$ \\
7 & 369290 & $31.0 \%$ & $5.6 \%$ & $5.4 \%$ & $1.9 \%$ & $0.1 \%$ & $43.9 \%$ & $-3.6 \%$ \\
8 & 434462 & $31.4 \%$ & $5.9 \%$ & $5.2 \%$ & $1.8 \%$ & $0.1 \%$ & $44.4 \%$ & $-3.3 \%$ \\
9 & 516660 & $32.2 \%$ & $6.6 \%$ & $4.9 \%$ & $1.6 \%$ & $0.0 \%$ & $45.3 \%$ & $-3.1 \%$ \\
10 & 718522 & $32.0 \%$ & $7.7 \%$ & $4.7 \%$ & $1.5 \%$ & $0.1 \%$ & $46.0 \%$ & $-2.6 \%$ \\
\hline
\end{tabular}

Table 6 shows that the social security contributions represent the most progressive part of the system, despite their flat-rate, no ceiling schedule. While the poorest decile pays only $2.7 \%$ of its market income in social contributions, the richest pays more than ten tomes more: $32 \%$. This is caused by the high concentration of households with a pension income among the poorer households.

Real distributive effects of the income tax are less progressive than would be expected given its schedule. But due to relatively generous tax deductions, even the richest decile pays only $7.7 \%$ in income tax.

Effect of consumption taxes is, as expected, regressive: poor households pay a higher share of their income in VAT ( $8 \%$ for the poorest decile, but only $4.7 \%$ for the richest). The effect of the excise taxes is hump-shaped: middle deciles pay highest shares of their income in the excise taxes while poorer and richer deciles pay less.

Table 6 brings also information on the tax credits' distributive effects. Tax credits share a similar pattern to the overall tax burden. While the poorest decile(s) benefit more, there is little difference between medium and higher incomes with respect to the tax credits' effects.

\section{Chart 2: Distributive effects of tax system components}

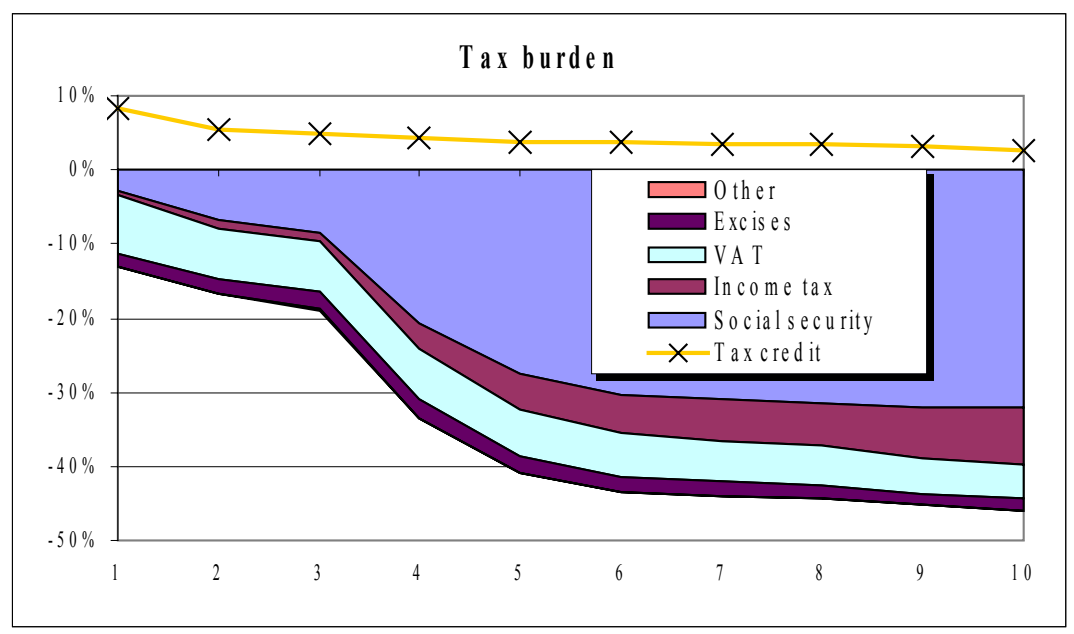

Chart 2 summarizes our findings graphically.

\section{Distributive effects of the social system}


This chapter draws on the paper Schneider, Jelínek (2004) in which we analyzed social benefits in a dynamic context. For purposes of this paper, however, we use just the 2001 data, as to be consistent with the tax analysis.

As the following table 7 shows, the Czech social security system was rather well targeted at the poorest decile whose income was boosted by almost $30 \%$ in 2001 . The system was less generous to the second poorest decile that gets "only" $14 \%$ increase in income. The third decile gets an $8 \%$ boost and the boost then uniformly decreases to about $5 \%$ for the fifth decile and eventually to about $1 \%$ for the richest decile - see table $7 .$.

Table 7: Income boosts received by different deciles from various schemes in 2001

\begin{tabular}{lcccccccc}
\hline & $\begin{array}{l}\text { Child } \\
\text { allow- } \\
\text { ances }\end{array}$ & $\begin{array}{l}\text { Social } \\
\text { supple- } \\
\text { ment }\end{array}$ & $\begin{array}{l}\text { Parental } \\
\text { allow- } \\
\text { ances }\end{array}$ & $\begin{array}{l}\text { Other } \\
\text { social } \\
\text { support }\end{array}$ & $\begin{array}{l}\text { Unemploy- } \\
\text { ment benefits }\end{array}$ & $\begin{array}{l}\text { Illness } \\
\text { benefits }\end{array}$ & TOTAL & Tax credits \\
\hline \hline Decile 1 & $6.0 \%$ & $4.9 \%$ & $6.3 \%$ & $3.2 \%$ & $1.3 \%$ & $6.9 \%$ & $\mathbf{2 9 . 3 \%}$ & $8.3 \%$ \\
Decile 2 & $3.6 \%$ & $1.1 \%$ & $3.0 \%$ & $1.1 \%$ & $0.5 \%$ & $3.9 \%$ & $\mathbf{1 3 . 6 \%}$ & $5.6 \%$ \\
Decile 3 & $2.1 \%$ & $0.1 \%$ & $1.8 \%$ & $0.3 \%$ & $0.5 \%$ & $2.6 \%$ & $\mathbf{7 . 8 \%}$ & $4.8 \%$ \\
Decile 4 & $1.8 \%$ & $0.1 \%$ & $0.8 \%$ & $0.2 \%$ & $0.4 \%$ & $2.4 \%$ & $\mathbf{5 . 7 \%}$ & $4.4 \%$ \\
Decile 5 & $1.3 \%$ & $0.0 \%$ & $0.6 \%$ & $0.2 \%$ & $0.4 \%$ & $1.9 \%$ & $\mathbf{4 . 4 \%}$ & $3.8 \%$ \\
Decile 6 & $0.9 \%$ & $0.0 \%$ & $0.1 \%$ & $0.1 \%$ & $0.2 \%$ & $1.8 \%$ & $\mathbf{3 . 1 \%}$ & $3.8 \%$ \\
Decile 7 & $0.4 \%$ & $0.0 \%$ & $0.1 \%$ & $0.1 \%$ & $0.2 \%$ & $1.9 \%$ & $\mathbf{2 . 9 \%}$ & $3.6 \%$ \\
Decile 8 & $0.3 \%$ & $0.0 \%$ & $0.1 \%$ & $0.0 \%$ & $0.1 \%$ & $1.5 \%$ & $\mathbf{2 . 0} \%$ & $3.3 \%$ \\
Decile 9 & $0.1 \%$ & $0.0 \%$ & $0.0 \%$ & $0.0 \%$ & $0.1 \%$ & $1.1 \%$ & $\mathbf{1 . 3 \%}$ & $3.1 \%$ \\
Decile 10 & $0.0 \%$ & $0.0 \%$ & $0.0 \%$ & $0.0 \%$ & $0.0 \%$ & $0.7 \%$ & $\mathbf{0 . 8 \%}$ & $2.6 \%$ \\
\hline
\end{tabular}

When we compare various social programs, we may identify three rather well targeted programs and three wider spread schemes. Best "targeted" social programs are the social supplement and the parental allowance scheme. The social supplement advances income of the poorest decile by $5 \%$ and all but ignores the six richest deciles altogether. Perhaps surprisingly, the parental allowance scheme is targeted very well: it moved up income of the poorest decile by more than $6 \%$ and the second decile's income by about $3 \%$, making little impact elsewhere.

Children allowances also do distribute towards the poorest decile (its income rises by $6 \%$ ), but they keep boosting income of all income groups, which makes them unnecessarily expensive. The illness and unemployment benefits are allegedly "insurance-based" but due to the severe ceilings on these benefits, they resemble standard social security schemes. That is why we can assess their redistribution effects. Table 7 shows that unemployment benefits are the better targeted of the two; illness benefits are much more spread, as they enhance the poorest income by $7 \%$, but the rest of population gets a $2-3 \%$ bonus as well.

Table 7 also shows the distribution impact of tax deductible allowances. We can see that they boosted the poorest decile's income by $8 \%$. Tax allowances are also, by their construction, less progressive than social benefits. The middle deciles' incomes were increased by $4-6 \%$ and the richest decile gained $2.6 \%$.

The following charts illustrate redistribution effects of various social security schemes graphically. Chart 3 shows how the income transfers to various deciles are structured, i.e. how much is contributed by various social schemes. The line shows impact of tax credits. 
Chart 3: Income increases from various social schemes 1999-2002(in \% of income)

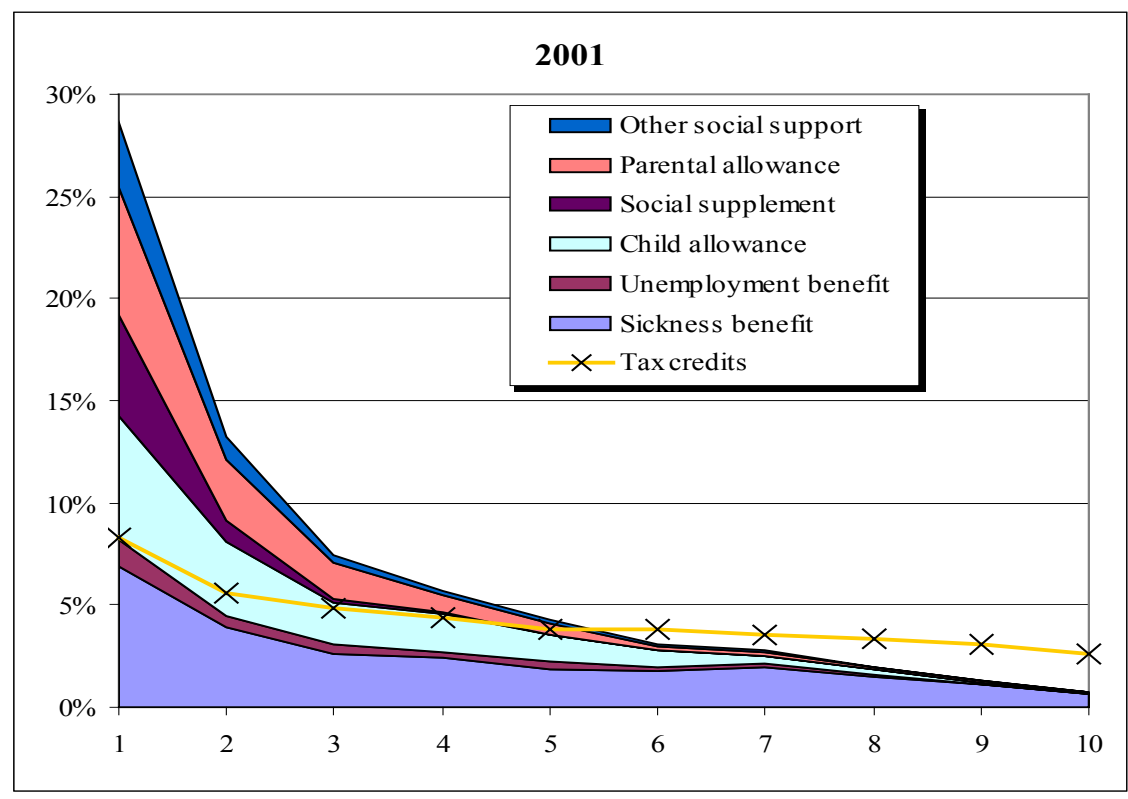

\section{Combined effects}

In this section, we will combine effects of the tax and social systems and see how Czech households fared vis-à-vis the combination of the two systems. For that purpose, we construct table 8 which combines main results from tables 6 and 7 .

The table demonstrates that the tax system (negative) effects are much stronger for most deciles than (positive) effects of the social transfers, i.e. income of eight deciles falls after the taxes are paid and social transfers paid. Only the two poorest deciles' incomes rise by almost a quarter for the poorest and negligibly for the second decile.

The very fact that $80 \%$ of households are left worse off is not a surprising result, as we compare two very different systems. Tax system collected CZK 782bn in 2001 (and tax credits "saved" some CZK 52bn for all households), while the social benefits considered in this analysis "returned" only CZK 70bn to households. The difference - more than CZK $700 \mathrm{bn}$ - was used for financing other government expenditures: pensions, health care, administration, defense and so on.

Still, the distributive effects of the taxes and social benefits considered in this paper are interesting. We observe that the system is very progressive in the lower half of the income distribution. The total difference of the systems' combined effects between the poorest and the fifth decile is massive 57 percentage points. It means that taxes are rising and social benefits are withdrawn fast as a household becomes upward mobile and moves from the poorest decile. This is another illustration of severe poverty trap identified on the microeconomic level in Schneider, Jelínek (2004).

On the other hand, the effects for deciles in the upper half of the income distribution differ only marginally, i.e. the combined tax and social systems are rather neutral for the upper part of the income distribution, albeit they are significant at about $40 \%$. This high level underlines heavy costs of the Czech tax (and social) system levied on incomes of households and indicates the size of the deadweight effects that manifests itself in persistent and high unemployment rate in the Czech Republic. 
Table 8: Combined effects of the tax and social systems on income of households in 2001 (\% of households' income)

\begin{tabular}{lccccc}
\hline & $\begin{array}{c}\text { Total tax } \\
\text { system }\end{array}$ & $\begin{array}{c}\text { Tax deductible } \\
\text { allowance }\end{array}$ & $\begin{array}{c}\text { TOTAL } \\
\text { TAXES }\end{array}$ & $\begin{array}{c}\text { Total social } \\
\text { system }\end{array}$ & TOTAL \\
\hline \hline Decile 1 & $-13.0 \%$ & $8.3 \%$ & $-4.8 \%$ & $29.3 \%$ & $\mathbf{+ 2 4 . 5 \%}$ \\
Decile 2 & $-16.9 \%$ & $5.6 \%$ & $-11.1 \%$ & $13.6 \%$ & $\mathbf{+ 2 . 5 \%}$ \\
Decile 3 & $-18.9 \%$ & $4.8 \%$ & $-14.1 \%$ & $7.8 \%$ & $\mathbf{- 6 . 2 \%}$ \\
Decile 4 & $-33.5 \%$ & $4.4 \%$ & $-29.1 \%$ & $5.7 \%$ & $\mathbf{- 2 3 . 4 \%}$ \\
Decile 5 & $-40.9 \%$ & $3.8 \%$ & $-37.1 \%$ & $4.4 \%$ & $\mathbf{- 3 2 . 7 \%}$ \\
Decile 6 & $-43.5 \%$ & $3.8 \%$ & $-39.8 \%$ & $3.1 \%$ & $\mathbf{- 3 6 . 7 \%}$ \\
Decile 7 & $-43.9 \%$ & $3.6 \%$ & $-40.4 \%$ & $2.9 \%$ & $\mathbf{- 3 7 . 5 \%}$ \\
Decile 8 & $-44.4 \%$ & $3.3 \%$ & $-41.1 \%$ & $2.0 \%$ & $\mathbf{- 3 9 . 1 \%}$ \\
Decile 9 & $-45.3 \%$ & $3.1 \%$ & $-42.2 \%$ & $1.3 \%$ & $\mathbf{- 4 0 . 1 \%}$ \\
Decile 10 & $-46.0 \%$ & $2.6 \%$ & $-43.4 \%$ & $0.8 \%$ & $\mathbf{- 4 2 . 6 \%}$ \\
\hline
\end{tabular}

Chart 4: Combined effects of the tax and social systems on income of households in 2001 (\% of households' income)

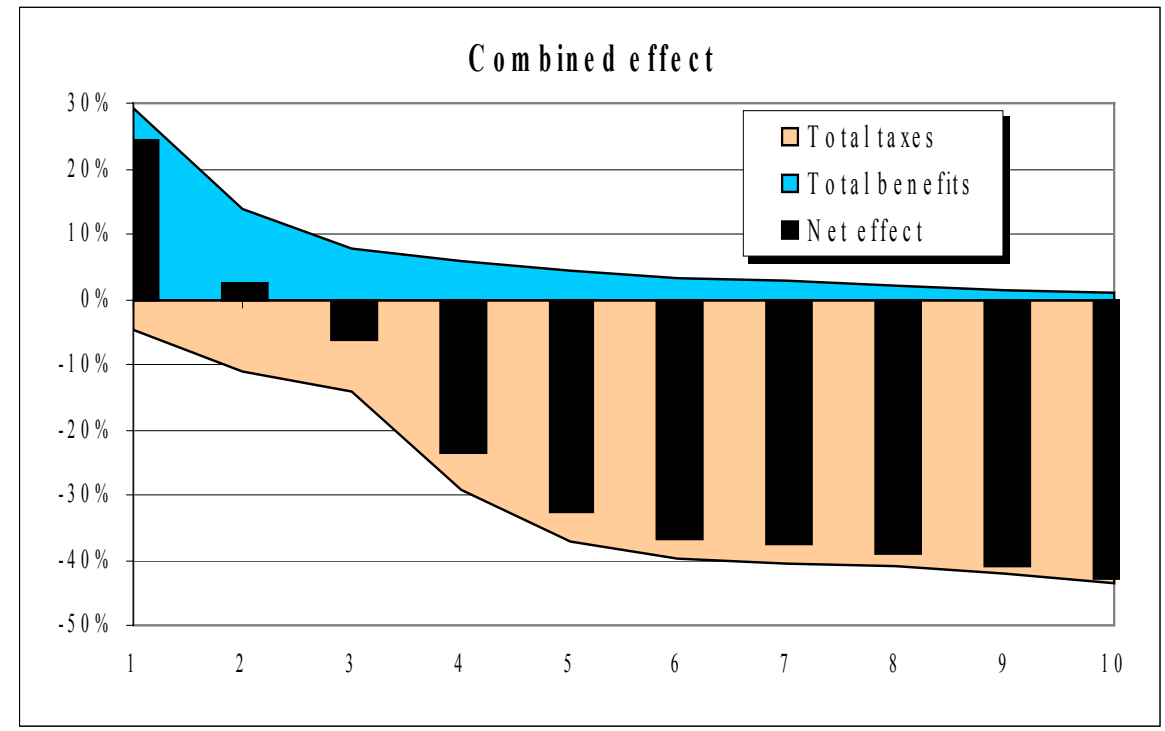

\section{Conclusions}

Our analysis of the tax and social systems' impact on household income distribution, which is monitored by Household Budget Surveys, has brought several results. First, we find that the tax system in the Czech Republic progresses heavily in the lower part of the income distribution, where taxes paid by lowest income decile are less than $5 \%$ of its income's income, but the share rises fast to $30 \%$ for the fourth decile and almost $40 \%$ for the median household. Taxes then remain high at $40-45 \%$, but there is no further progressivity in the upper half of income distribution.

Second, targeting of majority of social programs is quite good. More than one third of all expenses on six analyzed social benefits were spent on households in the lowest income decile. Three fourth of all expenses goes to households in the lower half of income spectrum. 
Third, when we combine these two systems, the resulting effect is very progressive in the lower half of the income distribution. As we noted earlier, taxes are rising and social benefits are withdrawn fast as a household becomes upward mobile (the total difference of the systems' combined effects between the poorest and the fifth decile is massive 57 percentage points). This is another illustration of severe poverty trap identified earlier at the microeconomic level.

Lastly, the effects for deciles in the upper half of the income distribution differ only marginally, i.e. the combined tax and social systems are rather neutral for the upper part of the income distribution, albeit they are significant at about 40\%. This high level underlines heavy costs of the Czech tax (and social) system levied on incomes of households and indicates the size of the deadweight effects that manifests itself in persistent and high unemployment rate in the Czech Republic.

We believe that our analysis demonstrates rather robustly that the Czech social and tax systems face an uncomfortable choice. They are both rather properly targeted, even though it is impossible to know whether targeting reflects society's preferences. This targeting, however, increases risks of poverty trap, as households risk losing benefits and paying more taxes as they increase their market income.

At the same time, implied tax rates are very high for a majority of households and thus they prevent any strategy that would eliminate poverty trap by increasing benefits (or lowering taxes) for poorer households while maintaining other government expenditures. Thus, if the poverty trap is to be mitigated, the strategy must pursue lowering transfers to the poorer households, not increasing taxes to richer households. 


\section{Literature}

Aaron, H. J., Pechman, J. A. (1981): How Taxes Affect Economic Behavior, The Brookings Institution, Washington, D.C.

Bezděk V., Stiller V. (2000): Modelování hlavních daňových př́ijmů české rozpočtové soustavy, Finance a úvěr, roč. 50 , č.2.

Bronchi, Ch., Burns, A. (2000): The tax system in the Czech Republic, OECD Economic Studies, No. 245.

Fullerton, D., Rogers, D. L. (1993): Who Bears the Life Tax Burden?, The Brookings Institution, Washington, D.C.

Fullerton, D., Metcalf, G., I. (2002): Tax Incidence, National Bureau of Economic Research, Working Paper 8829, Cambridge.

Jacobs, O. H., Spengel, Ch. (2002): Effective Tax Burden in Europe, Center for European Economic Research (ZEW), Manheim.

Joumardi I. (2002): Tax systems in European Union countries, OECD Economic Studies, No. 34.

Mitrusi, A., Poterba, J. (2000): The Distribution of Payroll and Income Tax Burdens, 19791999, NBER Working Paper Series, Working Paper 7707, Cambridge.

Newberry, David M.G. (ed.) (1995): Tax and Benefit Reform in Central and Eastern Europe, CEPR, London.

OECD (2001): Country Report: Czech Republic 2001, Centre on Tax Policy and Administration, OECD, Paris.

Pechman, J. A. (1989): Tax Reform, The Rich and the Poor, The Brookings Institution, Harvester Wheatsheaf, Hertfordshire.

Pechman, J. A. (1985): Who Paid the Taxes, 1966-85, The Brookings Institution, Washington, D.C.

Schneider Ondřej (2004): Protecting People While Enhancing Work Incentives: The Role of The Welfare System, in: Czech Republic: Ageing and Employment Policies, OECD, Paris 2004. ISBN: 92-64-01661-9.

Schneider Ondřej, Tomáš Jelínek (2004): Distributive Impact of Czech Social Security and Tax Systems: Dynamics in Early 2000's, Working Paper 67/2004, Institute of Economic Studies FSV UK

Schneider Ondřej, Martin Salí and Jan Zápal (2003): Zdanění práce a kapitálu - Teorie a aplikace na českou ekonomiku, ("Labour and Capital Taxation - Theory and Application to the Czech economy"). Finance a úvěr-Czech Journal of Economics and Finance 2003, vol. 53, No.11/12.

Schneider Ondřej (2003): Veřejné rozpočty v České republice v 90. letech - kořeny krize, ("Czech Public Budgets in the 90's - Roots of a Crisis"), in Czech, Working Paper 30/2003, Institute of Economic Studies FSV UK

Schneider Ondřej, Tomáš Jelínek (2001): Vliv českého sociálního systému a daňových úlev na rozdělení příjmů, ("Impact Of Czech Social Security System And Tax Deductible Allowance On The Income Distribution"), in Czech and English, Finance a úvěr $12 / 2001$.

Schneider Ondřej, Pavel Štěpánek (2001): A looming Financial Crisis in the Czech Republic, in: Dabrowski M., Rostowski J. (eds.) The Eastern Enlargement of the EU, Kluwer Academic Publishers.

Večerník Jiř́ and Petr Matějů (1999): Ten Years of Rebuilding Capitalism: Czech Society After 1989, Academia, Praha. 
Večerník Jiří (1996): Markets and People - The Czech Reform Experience in a Comparative Perspective, Avebury, Aldershot, England.

Večerník Jiří (2002).: Přerozdělování př́ijmů daněmi a dávkami v ČR: jeho proměny a reflexe po roce 1989, Finance a úvěr, roč. 52, 2002, č. 1

\section{Data:}

DATA - ČESKÝ STATISTICKÝ ÚŘAD: Statistika rodinných účtu, Př́ijmy, vydání a spotřeba rodinných účtů za rok 2001, Praha 2002 


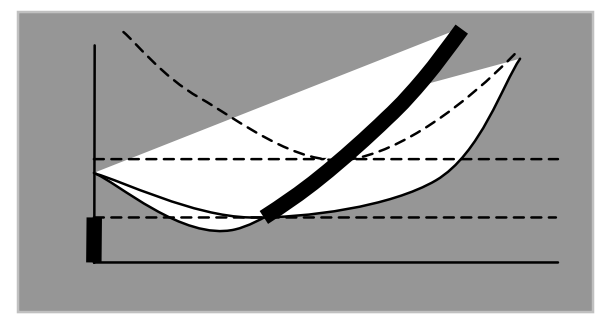

\section{Dosud vyšlo :}

1. Michal Hlaváček: Modely difuze technologii

2. Tomáš Cahlik : Analýza ekonomického výzkumu

3. Vladimír Benáček: : Autentický soukromý sektor v transitivní ekonomice: př́spěvek ke hledání kořenů a alternativ českého kapitalismu

4. Milan Sojka : Alternativni scénáře transformační strategie československé ekonomiky na počátku 90. let a jejich teoretická východiska

5. Jiř́ Hlaváček, Michal Hlaváček: Optimum výrobce v odvětvís nikdy neklesajícími výnosy z rozsahu

6. František Turnovec: The Czech Republic on its Way to the European Union

7. Lubomir Mlčoch : Ekonomie dìvěry

8. Luděk Urban : Zásady společné obchodní politiky a di̊sledky jejich přijetí pro českou ekonomiku

9. Jan Ámos Višek: Export z $\check{C} R$ do EU a mimo EU

10. Miloslav S. Vošvrda : On Martingale Diffusions in Financial Markets

11. František Turnovec :Flexible Integration and the Excessive Deficit Procedure in the EMU

12. Jiř́ Hlaváček, Michal Hlaváček: Byl proces eliminace podniků ozdravnou procedurou pro české hospodárstvi konce 90. let?

13. Karel Půlpán: Hospodářský vývoj Španělska jako inspirace pro Českou republiku.

14. Jiři Hlaváček, Michal Hlaváček: Ekonomicky racionálni altruismus

15. Jiř́ Kameníček : Nástroje pro popis nestandardního ekonomického chování, aplikace teorie lidského kapitálu

16. Jiři Hlaváček : Redistribuce : projev lidských preferencí a společenských potřeb

17. Silvester van Koten: Transaction Cost Economics: Basic Concepts and Extensions

18. Hlaváček J., Hlaváček M.: Ekonomická racionalita donátora a di̊věra k př́jemci dotace

19. Vladimír Benáček, Višsek Jan Ámos: Determining Factors of Competitiveness of Trade and Specialization of Czech Industrial Sector before the EU Accession

20. Milan Sojka, Postkeynesovská teorie peněz, peněžní a úvěrová politika a postavení centrální banky

21. Milan Sojka, Alternativni scénáře transformační strategie československé ekonomiky na počátku 90. let a jejich teoretická východiska

22. František Turnovec, Economic Research and Education in the Czech Republic 1989-2000

23. Jiři Hlaváček, Michal Hlaváček : Petrohradský paradox

24. František Turnovec: Evaluation of National, Political and Institutional Influence in Consultation, Cooperation and Co-decision Procedures of the EU Decision Making

25. Karel Půlpán: Rakouský poválečný vývoj

26. Ondřej Schneider : European Pension Systems and the EU Enlargement

27. Martin Gregor: Mancur Olson redivivus, ,,Vzestup a pád národü“ a současné společenské vědy”

28. Martin Gregor: Mancur Olson's Addendum to New Keynesianism: Wage Stickiness Explained

29. Patrik Nový : Olsonova teorie hospodářského cyklu ve světle empirie: návrh alternativního metodologického př́stupu

30. Ondřej Schneider: Veřejné rozpočty v ČR v 90. letech 20. století - kořeny krize

31. Michal Ježek: Mikroanalýza reformy českého důchodového systému

32. Michal Hlaváček: Efektivnost pořizení a předávání informace mezi privátními subjekty s pozitivněextenalitní vazbou

33. Tomáš Richter: Zástavní právo k podniku z pohledu teorie a praxe dluhového financování

34. Vladimír Benáček: Rise of an Authentic Private Sector in an Economy of Transition: De Novo Enterprises and their Impact on the Czech Economy

35. Tomáš Cahlík, Soňa Pokutová, Ctirad Slavik: Human Capital Mobility

36. Tomáš Cahlík, Jakub Sovina: Konvergence a soutěžní výhody ČR

37. Ondřej Schneider, Petr Hedbávný: Fiscal Policy: Too Political?

38. Jiř́ Havel: Akcionářská demokracie „Czech made“

39. Jiři Hlaváček, Michal Hlaváček: K mikroekonomickému klimatu v ČR na začátku 21.století: kartel prodejců pohonných hmot? (připadová studie)

40. Karel Janda: Credit Guarantees in a Credit Market with Adverse Selection

41. Lubomír Mlčoch: Společné dobro pro ekonomiku: národni, evropské, globální

42. Karel Půlpán: Hospodářský vývoj Německa jako inspirace pro Česko 
43. Milan Sojka: Czech Transformation Strategy and its Economic Consequences: A Case of an Institutional Failure

44. Luděk Urban: Lisabonská strategie, jeji hlavní směry a nástroje.

45. Jiři Hlaváček, Michal Hlaváček: Models of Economically Rational Donators

46. Karel Kouba, Ondřej Vychodil, Jitka Roberts: Privatizace bez kapitálu.

47. František Turnovec: Economic Research in the Czech Republic: Entering International Academic Marke.t

48. František Turnovec, Jacek W. Mercik, Mariusz Mazurkiewicz: Power Indices: Shapley-Shubik or PenroseBanzhaf?

49. Vladimír Benáček: Current Account Developments in Central, Baltic and South-Eastern Europe in the Preenlargement Period in 2002-2003

50. Vladimír Benáček: External FInancing and FDI in Central, Baltic and South-Eastern Europe during 20022003

51. Tomáš Cahlik, Soňa Pokutová, Ctirad Slavik: Human Capital Mobility II

52. Karel Diviš, Petr Teplý: Informační efektivnost burzovních trhů ve střední Evropě

53. František Turnovec: Česká ekonomická věda na mezinárodním akademickém trhu: měření vědeckého kapitálu vysokoškolských a dalšich výzkumných pracovišt'

54. Karel Půlpán: Měnové plánování za reálného socialismu

55. Petr Hedbávný, Ondřej Schneider, Jan Zápal: Does the Enlarged European Union Need a Better Fiscal Pact?

56. Martin Gregor: Governing Fiscal Commons in the Enlarged European Union.

57. Michal Mejstřik: Privatizace, regulace a deregulace utilit v EU a ČR: očekávání a fakta

58. Ilona Bažantová: České centrální bankovnictví po vstup České republiky do Evropské unie (právně institucionální pohled)

59. Jiři Havel: Dilemata českého dozoru finančnich trhů.

60. Irena Jindrichovská: Response of Regulatory Bodies to FInancial Crises: Role of Auditors and International Comparison

61. Karel Janda: Bankruptcy Procedures with Ex Post Moral Hazard

62. Ondřej Knot, Ondřej Vychodil: What Drives the Optimal Bankruptcy Law Design

63. Jiř́ Hlaváček, Michal Hlaváček: Models of Economically Rational Donators: Altruism Can Be Cruel

64. Alě̌ Bulǐr, Kateřina Šmidková: Would Fast Sailing towards the Euro Be Smooth? What Fundamental Real Exchange Rates Tell Us about Acceding Economies?

65. Gabriela Hrubá: Rozloženi daňového břemene mezi české domácnosti: př́mé daně

66. Gabriela Hrubá: Rozložení daňového břemene mezi české domácnosti: nepř́mé daně

67. Ondřej Schneider, Tomáš Jelinek: Distributive Impact of Czech Social Security and Tax Systems: Dynamics in Early 2000's.

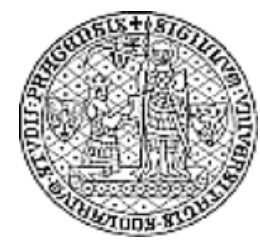

Univerzita Karlova v Praze, Fakulta sociálních věd,

Institut ekonomických studí́ [UK FSV - IES] Praha 1, Opletalova 26.

E-mail :ies@mbox.fsv.cuni.cz

http://ies.fsv.cuni.cz 